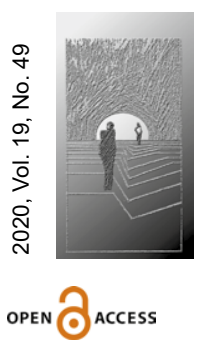

Michał Drożdż

ORCID: 0000-0002-8448-7607

Uniwersytet Papieski Jana Pawła II w Krakowie md00999@gmail.com

DOI: 10.35765/hw.1846

\title{
Medialne kreowanie klimatów rodzinnych
}

\section{STRESZCZENIE}

CEL NAUKOWY: Waga i znaczenie medialnych szans, wyzwań i zagrożeń dla rodziny wydają się wciąż mało uwzględniane, nie tylko w samym przekazie medialnym, ale również w świadomości współczesnych rodzin. Celem naukowym niniejszego artykułu jest próba pokazania wybranych aspektów wpływu mediów na rodzinę z perspektywy współczesnego dyskursu etycznego.

PROBLEM I METODY BADAWCZE: Zasadniczym problemem badawczym artykułu jest analiza konsekwencji oddziaływania mediów na środowiska rodzinne. Problem badawczy został sformułowany w tytule artykułu jako kreowanie przez media klimatów rodzinnych. W naszych analizach odwołujemy się do literatury źródłowej nauczania papieży Jana Pawła II i Franciszka na temat roli mediów wobec rodziny w kontekście współczesnych procesów cywilizacyjnych. Analiza szans, wyzwań i zagrożeń dla rodziny w dobie cywilizacji medialnej jest oparta na literaturze przedmiotowej dotyczącej tego zagadnienia oraz na własnych obserwacjach uczestniczących.

PROCES WYWODU: W niniejszych analizach staramy się ukazać wybrane aspekty rodzinnych klimatów kreowanych w zasadniczej mierze przez aktywną obecność mediów w środowiskach rodzinnych. Podstawową perspektywą analiz będzie perspektywa personalistyczna, stanowiąca szeroką platformę dialogu dla różnych orientacji i argumentacji etycznych.

WYNIKI ANALIZY NAUKOWEJ: Analizy naukowe zawarte w artykule pokazują pola powinności etycznych troski o rodzinę w świecie wielorakich oddziaływań medialnych. Głównymi wymiarami tej troski są: przestrzeganie zasad odpowiedzialności i szacunku dla godności człowieka w tworzeniu treści medialnych, wychowanie do odpowiedzialnego korzystania z mediów, poszukiwanie mechanizmów obronnych dla rodziny wobec zagrożeń medialnych.

WNIOSKI, INNOWACJE, REKOMENDACJE: Wszystkie zasady odpowiedzialnego tworzenia treści medialnych i korzystania z nich można sprowadzić do jednej podstawowej zasady: potrzeba się oprzeć na etyce mediów, która pozwala kształtować prawdziwe sumienie jako podstawowy regulator ludzkich wyborów i działań medialnych, zarówno działań twórców, nadawców, jak i odbiorców.

\section{$\rightarrow$ SŁOWA KLUCZOWE: MEDIA, RODZINA, ETYKA MEDIÓW, KLIMATY RODZINNE, FRANCISZEK}




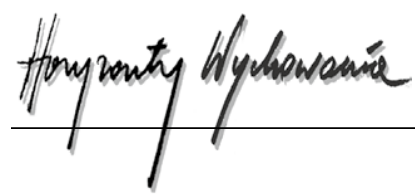

ABSTRACT

Creation of Family Atmosphere by the Media

RESEARCH OBJECTIVE: The importance of media opportunities, challenges and threats to the family still seem to be hardly considered, not only in the media message itself, but also in the minds of contemporary families. The scientific goal of this article is to attempt to show selected aspects of media influence on the family from the perspective of modern ethical discourse.

THE RESEARCH PROBLEM AND METHODS: The main research problem of the article is the analysis of the consequences of media effects on family environments. The research problem was formulated in the title of the article as the creation of family atmosphere by the media. In our analyzes, we refer to the source literature of the teaching of Popes John Paul II and Francis on the role of the media in relation to the family in the context of contemporary civilization processes.

THE PROCESS OF ARGUMENTATION: In these analyzes, we try to show selected aspects of family atmosphere created mainly by the active presence of the media in family environments. The basic perspective of the analysis will be the personalistic perspective, constituting a broad dialogue platform for various orientations and ethical arguments.

RESEARCH RESULTS: The scientific analyzes contained in the article show the fields of ethical obligations of caring for the family in the world of multiple media interactions. The main dimensions of this concern are: adherence to the principles of responsibility and respect for human dignity in creating media content, education for responsible media use, seeking defensive mechanisms for the family in the face of media threats.

CONCLUSIONS, INNOVATIONS, AND RECOMMENDATIONS: All the principles of responsible media content creation and use can be reduced to one basic principle: We need to rely on the ethics of the media, which allows us to shape a true conscience as the basic regulator of human choices and media activities, both of the creators, broadcasters and recipients.

\section{$\rightarrow$ KEYWORDS: MEDIA, FAMILY, MEDIA ETHICS, FAMILY ATMOSPHERE, FRANCIS}

\section{Potrzeba klimatu medialnej troski o rodzinę}

Rodzina staje dziś, na początku trzeciego tysiąclecia, w epoce medialnej i informacyjnej, wobec wielu wyzwań. Szczególnie w przestrzeni oddziaływania środków masowego przekazu jawią się nowe wyzwania, szanse i zagrożenia dla rodziny, dla jej wartości, godności i powołania. Wystarczy prosta obserwacja życia, aby się przekonać, że nie ma dzisiaj już domostw, nie ma też rodzin bez mediów. To one warunkują w sposób bardzo poważny nie tylko wychowanie dzieci i młodzieży, ale przede wszystkim cały klimat duchowy i kulturę (nie tylko masową) dzisiejszego człowieka, rodząc - obok zasadniczego pozytywnego wpływu - wiele nowych zagrożeń dla rodziny. Waga i znaczenie medialnych 
zagrożeń dla rodziny są wciąż mało uwzględniane, nie tylko w samym przekazie medialnym, ale również w świadomości współczesnych rodzin. Dlatego wydaje się, że zagadnienie wpływu mediów na dobro rodziny jest tematem aktualnym współczesnej dyskusji etycznej i tym bardziej może i powinno się stać przedmiotem analiz naukowych. W niniejszych analizach staramy się dotknąć tego problemu, czyniąc przedmiotem naszych refleksji zagadnienie odpowiedzialności i sprawiedliwości w mediach jako fundament budowania etyki mediów, służącej zarówno odbiorcom, jak i nadawcom oraz twórcom medialnym (por. Drożdż, 2005, s. 511-550). Podstawową perspektywą analiz będzie perspektywa personalistyczna, stanowiąca szeroką platformę dialogu dla różnych orientacji i argumentacji etycznych (por. Drożdż, 2006, s. 771-808).

Jan Paweł II w swoim ostatnim liście apostolskim Szybki rozwój (Jan Paweł II, 2005) wskazuje na podstawowy obowiązek Kościoła i wszystkich, którym powierzono troskę o rodzinę, by wnosili nieustannie wkład w lepsze rozumienie perspektyw i odpowiedzialności związanych z aktualnym rozwojem społecznego przekazu.

Właśnie dlatego, że [media] wpływają na sumienia jednostek, formują ich mentalność
i określają widzenie spraw, należy w zdecydowany i wyraźny sposób powtórzyć, że na-
rzędzia społecznego przekazu należą do organicznej struktury praw i obowiązków, zarów-
no z punktu widzenia formacji i odpowiedzialności etycznej, jak i w odniesieniu do ustaw
i kompetencji instytucjonalnych. Wszyscy i każdy odpowiedzialni są za pozytywny rozwój
mediów na służbie dobra wspólnego. Ze względu na silne więzy, jakie media mają z go-
spodarką, polityką i kulturą, konieczny jest taki system zarządzania, który byłby w stanie
zagwarantować centralne miejsce godności osoby, prymat rodziny, podstawowej komór-
ki społecznej oraz poprawnych relacji między różnymi podmiotami (Jan Paweł II, 2005).

Troska o prymat rodziny powinna być podstawowym zadaniem każdej etyki mediów, która jest i powinna być podstawowym narzędziem profesjonalnego dziennikarstwa. Korzystanie z tego narzędzia jest konieczne, szczególnie w sytuacji, kiedy

razem z wolnością wypowiedzi wszedł - przede wszystkim na antenę radia i telewizji wulgarny język ulicy. Nagminne jest też uporczywe epatowanie przemocą, brutalnością, mrocznością i obscenicznością oraz cynizm i hardość. Wielu odbiera to z niesmakiem, jako psychiczne molestowanie i pogwałcenie ich wolności wyboru. Czas z tym skończyć. W imię odpowiedzialności za człowieka, dziennikarze powinni opowiedzieć się bardziej zdecydowanie po stronie dobra i piękna. Trzeba, aby przeciwstawili się epatowaniu złem. Trzeba, aby naprawdę wewnętrznie wolni, prawi i kompetentni służyli sprawie godności ludzkiej (Konferencja Episkopatu Polski, 2009, nr 162).

Drugim, jeszcze poważniejszym problemem do przemyślenia w środowisku dziennikarskim - na który zwraca uwagę dokument Służyć prawdzie o małżeństwie i rodzinie jest wielokrotnie i na różne sposoby manifestowana niechęć do tradycyjnej rodziny.

Jest ogromnie pilne i potrzebne, aby wszyscy twórcy kultury masowej - mając też przed oczyma ich własne, najgłębsze marzenia o miłości i rodzinie, a przede wszystkim to, co najświętsze w ludzkim życiu i sercu - zechcieli się spokojnie zastanowić, po co negować, 


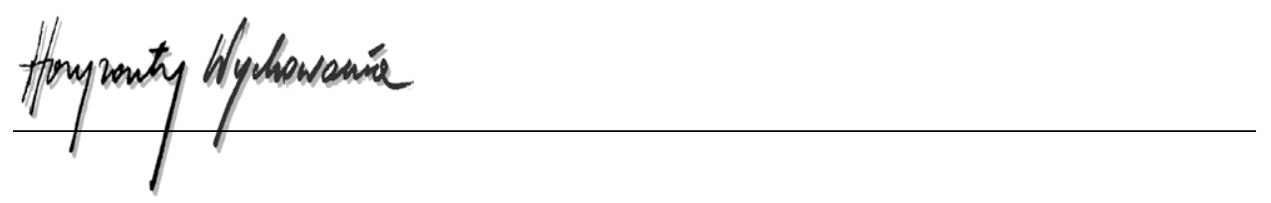

że człowiek jest powołany i zdolny do miłości, do ofiary i do budowania prawdziwej i trwałej jedności małżeńskiej między kobietą i mężczyzną? Po co jako ideał ludzkiej wolności przedstawiać karykaturę człowieka, schlebiając najniższym jego instynktom? Po co stwarzać wrażenie, że wszelkie słabości i nieprawości, przez które miłość ludzka bardzo często doznaje sprofanowania, a które Pismo Święte ukazuje od tysiącleci jako zupełnie sprzeczne z powołaniem człowieka do świętości, stanowią poszukiwaną przez wielu wartość? W imię czego bronić i wzywać do tolerancji tego, co złe i niedopuszczalne w świetle powszechnie przyjętych i przeżywanych wartości, obrażając większość społeczeństwa? Dlaczego przylepiać nieuczciwe i kłamliwe etykietki, nazywając zacofanymi i fundamentalistami tych, którzy bronią życia i godności ludzkiej? Czy człowieczeństwo przestało już być dla nas wszystkich „wspólnym mianownikiem” do dyskusji i zrozumienia? (Konferencja Episkopatu Polski, 2009, nr 163).

Te pytania postawione przez dokument Konferencji Episkopatu Polski stanowią podstawę do refleksji etycznej nad jakością sumień ludzi zaangażowanych w medialną komunikację masową. Stanowią one także osnowę niniejszych analiz nad potrzebą medialnej troski o rodzinę dla dobra całego społeczeństwa z perspektywy moralnego klimatu wprowadzanego do rodziny przez współczesne media.

\section{Klimat powszechnej medialności}

Nasza kultura stała się kulturą medialną. Dziś niemal wszystko jest medialne (por. Burakowska, 1996; Burszta, 1999, s. 25-38). Potoczna praktyka językowa pokazuje, że w znaczeniu szerszym mianem „mediów” nazywa się opłaty za utrzymanie domu, czyli opłaty za energię elektryczną, ogrzewanie, gaz wodę i wywóz śmieci. Nie ulega wątpliwości, że dotąd niewiele się pisze o wpływie tych „czynników” na życie ludzi, zarówno dorosłych, jak i dzieci oraz młodzieży. Jeżeli brakuje pieniędzy na podstawowe i godne utrzymanie rodziny, to braki te wywołują wiele smutnych i negatywnych postaw wobec życia (por. Bogucka, 2000, s. 20-25). Z kolei, jeżeli zaspokojenie podstawowych potrzeb nie sprawia w wielu rodzinach żadnych kłopotów, to okazuje się, że bezkrytycznie wyrasta pokolenie ludzi konsumistycznych (por. Drożdż, 1998, s. 24n; Brozi, 1992, s. 14n; Buttiglione, 1995, s. 95-103). Tak rozumiane „media” - w sposób niezbity warunkują życie dzisiejszego człowieka albo w stronę jego dobrego rozwoju, albo w stronę degradacji moralno-osobowej (por. Czerwiński, 1999, s. 110-116; Czarnik, 1996, s. 55-61; Goban-Klas, 2005, s. 10-114).

Ze świata mediów w znaczeniu szerszym wyróżnia się dziś przede wszystkim mass media, czyli środki społecznego przekazu i komunikowania się ludzi (Jan Paweł II, 2002b, s. 120-127; Benedykt XVI, 2007, s. 5-7). Już w Orędziu na Światowy Dzień Środków Społecznego Przekazu w 1980 r. Jan Paweł II wyjaśnia:

Niewątpliwie też środki społecznego przekazu są cennym źródłem ubogacenia kulturalnego zarówno jednostek, jak i całej rodziny. (...) W ten sposób środki społecznego przekazu mogą przyczynić się znacznie do zbliżenia serc ludzkich w życzliwości, wzajemnym zrozumieniu i braterstwie. Przy ich pomocy więź uczuciowa rodziny z całym rodzajem ludzkim 
stanie się ściślejsza i głębsza. Dobrodziejstw tych nie można nie doceniać (Jan Paweł II, 2002a, s. 90-96).

Trzeba być także świadomym rozlicznych zagrożeń ze strony mediów, które mogą być źle wykorzystane przez człowieka. Problemem bowiem nie są nowe technologie przekazu. One są same w sobie dobrem i człowiek powinien je wykorzystywać. Zagrożeniem dla osoby jest natomiast brak umiejętności właściwego odnoszenia się do mediów i poprawnego posługiwania się nimi. Problemy jawią się dopiero wtedy, gdy sposób korzystania z nowoczesnych środków przekazu jest niewłaściwy, a jest takim wtedy, gdy zagraża samorealizacji osoby lub niszczy osobowe relacje międzyludzkie. Można wymienić kilka podstawowych warunków odpowiedzialnego korzystania z mediów. Pierwszym jest odrzucenie konsumpcyjnego podejścia do nich, a zwłaszcza do telewizji i komputera. Konsumowanie mediów, pozbawione samokontroli, zawiera w sobie wyjątkowy paradoks, dotyczący skutków oddziaływania. Pozornie bowiem człowiek jest całkowicie pochłonięty przez proces społecznego komunikowania, a w rzeczywistości oddala się od faktycznego życia i traci zdolność do wchodzenia w relacje z realnymi osobami. Następnym warunkiem odpowiedzialnego korzystania ze środków przekazu jest umiejętność bezpośredniego odnoszenia się do rzeczywistości, z której pozorem mamy do czynienia w przekazach medialnych. $Z$ tej też racji jednym z ważnych elementów w procesie wychowania odbiorców jest kształtowanie postawy zainteresowania realnym światem. Celem tego wychowania winna być umiejętność przedkładania bezpośrednich doświadczeń nad doświadczeniami medialnymi. Kolejnym aspektem wychowania do odbioru mediów jest kształtowanie umiejętności aktywnego udziału w procesie społecznego komunikowania. Bierni odbiorcy stymulują media negatywnie, tzn. wspierają je w przekazach typowo konsumpcyjnych, powierzchownych i uproszczonych. W kompetentnym obchodzeniu się z elektronicznymi środkami pomocne jest też poznanie technik produkcji, przekazu, selekcji, a także technik manipulacji, propagandy i public relations (por. Lepa, 2001, s. 97-131).

Wszystkie te zasady czy rady można sprowadzić do jednej głównej. Potrzeba się oprzeć na etyce mediów, która pozwala kształtować prawdziwe sumienie jako podstawowy regulator ludzkich wyborów i działań medialnych, zarówno działań twórców, nadawców, jak i odbiorców.

\section{Klimat troski o wartości rodzinne}

Istnienie wartości jest pewne, tak jak pewne jest istnienie moje i drugiego człowieka (objawione poprzez rzeczywistość roztropności, umiarkowania, sprawiedliwości, męstwa i miłości - co potwierdza ten, kto kocha). Kiedy jednak zapytamy, czym jest wartość, popadamy w zakłopotanie (Stróżewski, 1965, s. 399-407; por. Krąpiec, 1965, s. 1129-1146; Crosby, 2004, s. 12-20; Półtawski, 2004, s. 41-51; Garello, 2002, s. 355-369). Termin „wartość" rozpoczął swoją karierę w XVIII w., najpierw w ekonomii, potem dopiero w filozofii i innych dziedzinach kultury. Pojęcie wartości jest więc nowożytne i wywodzi się 


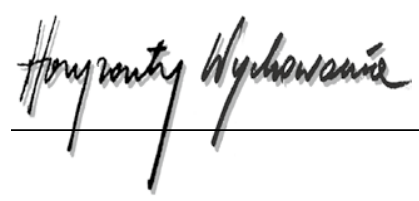

z innej niż etyczna dziedziny, niemniej sama czynność wartościowania oraz wypowiadanie sądów oceniających sięga fundamentów ludzkiej egzystencji (Piłat, 2001, s. 251259). Jest to bowiem podstawowy sposób zachowania się człowieka wobec świata. W odróżnieniu od zwierząt człowiek odznacza się wrażliwością aksjologiczną i dopiero dzięki wartościom życie jego nabiera sensu. Idea człowieczeństwa zakłada także, że człowiek jest bytem stojącym wobec wartości i na realizację tych wartości niejako „skazanym" - jeśli tylko naprawdę chce być człowiekiem (Piłat, 2001, s. 252). Dlatego też rodzina może i powinna się stać pierwszym miejscem humanizacji pojedynczych osób i całego społeczeństwa. Nie ma i nie może też być innej drogi promowania wartości ludzkich i chrześcijańskich, jak właśnie w rodzinie i przez zdrową moralnie oraz duchowo rodzinę. Chodzi więc to, aby rodzina miała wyraźną świadomość swojej tożsamości, gdyż ona jest warunkiem stabilności społeczeństw i całych narodów.

Wobec zagrożeń rodziny współczesnej, ze względu na lansowaną powszechnie w mediach laicyzację oraz demoralizację społeczeństwa, istnieje konieczność promowania wartości rodzinnych we wszystkich mediach. Problem polega na tym, że znając stan mediów i ich kondycję strukturalno-programową, można stwierdzić, iż promowanie wartości rodzinnych obecne jest tylko w niewielu mediach. Tymczasem każdy człowiek i każda społeczność potrzebują wartości, by trwać i rozwijać się integralnie w ludzkich wymiarach bycia i życia. Wartości jednak nie są dane człowiekowi i społeczeństwu na zawsze. Te same wartości mogą odgrywać ważną rolę, nabierać znaczenia, jak też słabnąć w świadomości i działaniach jednostek oraz społeczeństw. Człowiek sprzeniewierzający się wartościom, które są podstawą jego rozwoju, słabnie i ginie, a społeczeństwo gubiące wartości, na podstawie których się rozwinęło, rozpada się, traci znaczenie i degeneruje się, idąc w zapomnienie. Człowiek i społeczeństwo bez wartości są kruche, ale same wartości lekceważone nawet przez człowieka nie tracą swojego znaczenia. Człowiek więc, uczestniczący w przestrzeni medialnej, koniecznie potrzebuje wartości dla życia godnego osoby ludzkiej, a wartości potrzebują człowieka jako swego podmiotu odkrywania i urzeczywistniania (por. Dyczewski, 2001, s. 311). Ludzie mediów uczestniczą w masowym komunikowaniu wartości, mają podstawowy obowiązek troski o wartości służące integralnemu rozwojowi człowieka i społeczności.

\section{Klimat sprzeciwu wobec „kultury wykluczenia”}

Papież Franciszek podejmuje stałą troskę Kościoła o rodzinę w nowej sytuacji wyzwań strukturalnego ubóstwa wielu rodzin współczesnego świata. W adhortacji apostolskiej Evangelii gaudium tak ukazuje niektóre aspekty życia współczesnej rodziny:

Rodzina przechodzi głęboki kryzys kulturowy, podobnie jak wszystkie wspólnoty oraz więzi społeczne. W przypadku rodziny kruchość więzi staje się szczególnie poważna, ponieważ chodzi o podstawową komórkę społeczeństwa, o miejsce, gdzie człowiek uczy się współżycia w różnorodności i przynależności do innych i gdzie rodzice przekazują dzieciom wiarę. Istnieje skłonność, by widzieć małżeństwo jako czystą formę uczuciowej gratyfikacji, którą 
można ustanowić w jakikolwiek sposób oraz zmienić zależnie od wrażliwości każdego. Jednakże nieodzowny wkład małżeństwa w życie społeczne przekracza poziom uczuciowości i potrzeb dotyczących pary. Jak nauczają francuscy biskupi, nie rodzi się ono „z miłosnego uczucia", z definicji ulotnego, lecz z głębi zobowiązania przyjętego przez małżonków, którzy zgadzają się, by wejść w całkowitą wspólnotę życia (Franciszek, 2013).

Podobnie mocno wypowiada się ojciec święty, dając diagnozę mentalności antyrodzinnej w dzisiejszej kulturze, w przemówieniu w Dniu Rodzin 26 października 2013 r. na zakończenie Roku Wiary:

Życie często jest trudne. Także wiele razy tragiczne - usłyszeliśmy o tym przed chwilą. Praca jest trudem; poszukiwanie pracy jest trudem. Znalezienie dziś pracy wymaga od nas bardzo wielkiego trudu. Ale to, co w życiu ciąży najbardziej, to nie to, ale brak miłości. Ciężko nam, kiedy nikt się do nas nie uśmiecha, kiedy nie jesteśmy akceptowani. Ciążą pewne milczenia, czasem nawet w rodzinie, między mężem a żoną, między rodzicami a dziećmi, między braćmi. Bez miłości trud staje się jeszcze cięższy, nie do zniesienia. Myślę o osobach starszych, które są same, o rodzinach przeżywających trudności, ponieważ nie doświadczają pomocy i wsparcia dla tych osób w domu, które potrzebują specjalnego zainteresowania i troski (Rodziny, żyjcie radością wiary, 2013).

Ojciec święty Franciszek mówi stanowcze „nie” - jak to z mocą moralnego autorytetu określa - dla „ekonomii wykluczenia”:

podobnie jak przykazanie „nie zabijaj” ustala jasne granice dla zabezpieczenia wartości ludzkiego życia, dzisiaj musimy powiedzieć „nie” dla ekonomii wykluczenia i nierówności społecznej. Ta ekonomia zabija. Nie może tak być, że nie staje się wiadomością dnia fakt, iż z wyziębnięcia umiera starzec zmuszony żyć na ulicy, natomiast staje się nią spadek na giełdzie o dwa punkty. To jest wykluczenie. Nie można dłużej tolerować faktu, że wyrzuca się żywność, gdy ludzie cierpią głód. To jest nierówność społeczna. Dzisiaj wszystko opiera się na grze i rywalizacji, a prawo sprzyja silniejszym, więc możny pożera słabszego. W wyniku tej sytuacji wielkie masy ludności są wykluczone i marginalizowane: bez pracy, bez perspektyw, bez dróg wyjścia. Samego człowieka uważa się za dobro konsumpcyjne, którego można użyć, a potem je wyrzucić. Daliśmy początek kulturze „odrzucenia”, którą wprost się promuje. Nie chodzi już po prostu o zjawisko wyzysku i ucisku, ale o coś nowego: przez wykluczenie dotyka się samego korzenia przynależności do społeczeństwa, w którym człowiek żyje, jako że nie jest w nim na samym dole, na peryferiach, lub bez władzy, ale jest poza nim. Wykluczeni nie są „wyzyskiwani”, ale są odrzuceni, są „niepotrzebnymi resztkami” (Franciszek, 2013).

\section{Klimat troski o potrzeby materialne rodziny}

Papież Franciszek wielokrotnie powraca do oceny rzeczywistej sytuacji materialnej dzisiejszych rodzin. Jeszcze w Roku Wiary, w październiku 2013 r., ukazuje następujący fenomen:

Rodziny - z tym zaufaniem do wierności Boga stawiają czoło wszystkiemu, bez lęku, odpowiedzialnie. Chrześcijańscy małżonkowie nie są naiwni, znają problemy i niebezpieczeństwa życia. Ale nie boją się podjąć swojej odpowiedzialności przed Bogiem i społeczeństwem. 


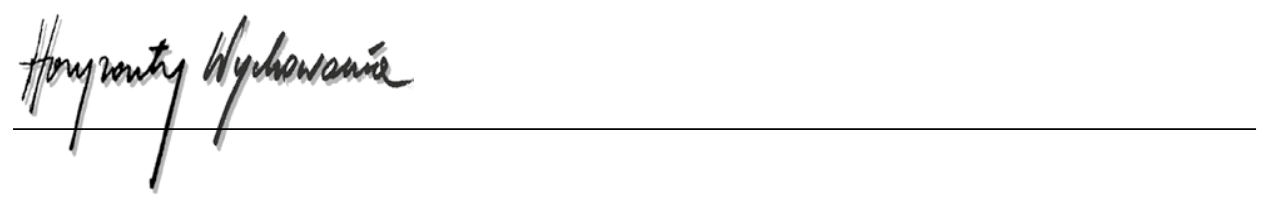

Nie uciekając, nie izolując się, nie rezygnując z misji tworzenia rodziny i rodzenia dzieci. Ależ Ojcze, dzisiaj to trudne... - Pewnie, że to trudne. Dlatego potrzebujemy łaski sakramentu! Sakramenty nie są po to, żeby być dekoracją życia. Jaki piękny ślub, jakie wspaniałe wesele - to nie jest łaska sakramentu. To pewna dekoracja. Łaska nie jest po to, żeby przyozdabiać życie. Jest po to, żeby dać nam moc, żebyśmy byli dzielni, żebyśmy mogli iść naprzód! (Rodziny, żyjcie radością wiary, 2013).

Z jeszcze większym zatroskaniem o pomyślny status materialny każdej rodziny dopomina się papież Franciszek w Evangelii gaudium, kiedy wypowiada stanowcze "nie” dla „ekonomii wykluczenia” (Franciszek, 2013) oraz „nie” dla „nowego bałwochwalstwa pieniądza" (Franciszek, 2013).

Ekonomia, jak wskazuje samo słowo, powinna być sztuką dochodzenia do odpowiedniego zarządzania wspólnym domem, jakim jest cały świat. Każda znacząca działalność ekonomiczna, podjęta w jakiejś części planety, ma wpływ na całość; dlatego żaden rząd nie może działać poza kręgiem wspólnej odpowiedzialności. Rzeczywiście, coraz trudniejsze staje się znalezienie rozwiązań na poziomie lokalnym z powodu ogromnych sprzeczności globalnych, stąd w polityce lokalnej przybywa coraz więcej problemów do rozwiązania. Jeśli rzeczywiście chcemy osiągnąć zdrową ekonomię światową, w obecnej fazie historycznej potrzebny jest pewien bardziej skuteczny sposób interakcji, który nie naruszając suwerenności narodów, zapewni dobrobyt ekonomiczny wszystkich krajów, a nie tylko nielicznych (Franciszek, 2013).

Do tych zagadnień papież pochodzi bardzo osobiście. Mocno bowiem brzmią jego słowa skierowane do młodych:

Wysłuchałem waszych doświadczeń, opowiedzianych przez was historii. Widziałem tak wiele dzieci, tak wielu dziadków... Odczułem ból rodzin, które żyją w sytuacji ubóstwa i wojny. Słuchałem ludzi młodych, którzy chcą się pobrać, pomimo tysięcy trudności. Stawiamy więc sobie pytanie: jak dzisiaj w rodzinie można żyć radością wiary? Pytam się was, czy możliwe jest życie tą radością, czy też nie? (Rodziny, żyjcie radością wiary, 2013).

W kontekście tak opisanych sytuacji ojciec święty odpowiada na te i tym podobne pytania bardzo egzystencjalnie i wręcz osobistym świadectwem. Słychać to m.in. w słynnych słowach skierowanych do młodzieży w Asyżu:

Nasi rodzice, dziadkowie i pradziadkowie, chociaż pobierali się często w trudniejszych warunkach niż obecnie, niekiedy w czasie wojny lub tuż po niej bądź jako imigranci, czerpali siłę z tej pewności, że Pan jest z nimi, że Bóg pobłogosławił rodzinę swym sakramentem oraz że błogosławiona jest również misja wydawania na świat dzieci i wychowywania ich. Dzięki temu mogli pokonywać najcięższe próby, była to prosta pewność, ale prawdziwa, tworząca kolumny wspierające ich miłość (Zawsze ufajcie Bogu, 2013).

Analizując sytuację współczesnych rodzin, ojciec święty Franciszek przypomina konieczność rozwiązania dwóch ważnych, rzutujących przede wszystkim na rodzinę, problemów. Pierwszy - dotyczy tego, iż w uwarunkowaniach wolnego rynku 
nie zdając sobie z tego sprawy, stajemy się niezdolni do współczucia wobec krzyku boleści innych, nie płaczemy już wobec dramatu innych ani nie interesuje nas troska o nich, tak jakby odpowiedzialność za to nas nie dotyczyła. Kultura dobrobytu nas znieczula i tracimy spokój, jeśli rynek oferuje coś, czego jeszcze nie kupiliśmy, podczas gdy zrujnowane życie tych wszystkich ludzi z powodu braku szans wydaje nam się zwykłym spektaklem, który nas wcale nie porusza (Franciszek, 2013).

I dlatego konieczne jest rozwiązanie drugiego zespołu problemów.

Nie można zwlekać - mówi Franciszek - z niezbędnym rozwiązaniem kwestii strukturalnych przyczyn ubóstwa, nie tylko ze względu na wymogi pragmatyczne, aby uzyskać rezultaty i wprowadzić ład w społeczeństwie, ale żeby je uzdrowić z choroby, która czyni je kruchym i niegodnym i która prowadzi tylko do nowych kryzysów. Plany pomocy, stawiające czoło niektórym pilnym potrzebom, trzeba traktować jedynie jako odpowiedzi prowizoryczne. Dopóki nie rozwiąże się radykalnie problemów ludzi ubogich, rezygnując z absolutnej autonomii rynków oraz spekulacji finansowych, atakując strukturalne przyczyny nierównowagi, nie rozwiąże się problemów świata - i ostatecznie żadnego problemu. Nierównowaga stanowi korzeń chorób społecznych (Franciszek, 2013).

Najbardziej negatywnie i destrukcyjnie odbija się to przede wszystkim na życiu rodzin.

\section{Klimat „wolności przeciw naturze ludzkiej”}

Świat mediosfery jest światem stworzonym przez człowieka. Powinien być zatem z gruntu „światem ludzkim”. Tymczasem życie uczy, że tak nie jest. Dziś jesteśmy świadkami dosyć złożonej serii zjawisk, w których media - w imię niczym nieograniczonej wolności człowieka - stają „przeciw naturze ludzkiej” (zob. Szostek, 1990; Buttiglione, 1991a; Buttiglione, 1991b; Laun, 1991). Wszystko to bardzo silnie rzutuje na życie rodzinne. W związku z tym trzeba postawić pytanie: w czym leży sedno tych prowokacji? Otóż pytanie: „Osoba ludzka: wolność przeciwko naturze?” jest oczywiście skrótem. Raczej trzeba by powiedzieć: „Osoba ludzka: wolność ludzka przeciwko ludzkiej naturze czy wolność ludzka w służbie ludzkiej natury?”. Pytanie to wskazuje na dychotomiczną alternatywę. Wedle takiego ujęcia dwu członów alternatywy - chodzi o ewentualną prawomocność takiej definicji osoby ludzkiej, zgodnie z którą jedyną cechą, która konstytuuje ludzką osobę w jej istocie, jest sama tylko wolność (zob. Styczeń, 1991, s. 15-24).

Osoba ludzka byłaby wówczas po prostu czystą samozależnością. Owa samozależność stanowiłaby o samej naturze osoby, przeciwstawiając ją tym samym niejako 'z natury' wszelkiej innej naturze człowieka jako czemuś, co wobec osoby jako osoby jest zewnętrzne, heterogeniczne, poniekąd obce. Zgodnie z tym ujęciem - częstym w dzisiejszych teoriach mediów - człowiek odkrywając samego siebie w akcie swego samopoznania - jawi się samemu sobie jako wolność odniesiona - w imię swej tożsamości - wyłącznie i wprost tylko do samej wolności. Co więcej - wolność tak rozumiana nie związana niczym innym w imię prawdy o sobie - poza samą wolnością (Styczeń, 1991, s. 16). 


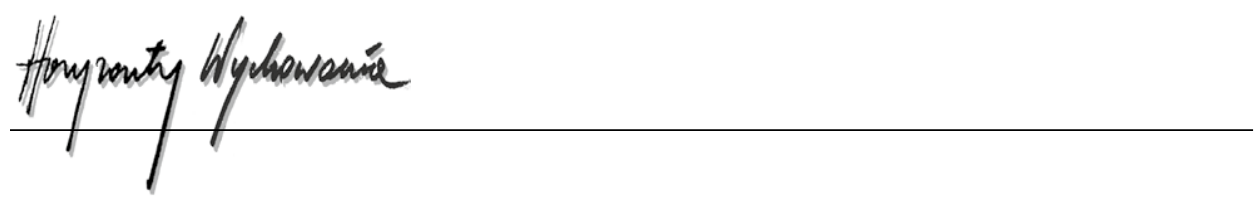

W związku z tym media „czują się” upoważnione do robienia różnych prób i wszelkich manipulacji. Nie czują się zobowiązane do respektowania uniwersalnych powinności moralnych. Nie czują się w większości - zobowiązane do respektowania zwłaszcza prawidłowości rządzących cielesną stroną ludzkiej rzeczywistości. W praktyce oznacza to redukcję człowieka jako osoby do jego naturalnych skłonności przyjemnościowych i - odpowiednio - zaniżenie norm moralnych, czyli etyki, do praw biologii (jest to złudzenie naturalistyczne, biologizacja etyki). Natura człowieka jest bowiem - w tej wizji osoby ludzkiej - zawsze „zewnętrzna” w stosunku do „natury” osoby jako osoby (Styczeń, 1991, s. 17). Tak rozumiany człowiek jawi się w mediach jako wybitnie „ograniczony”. Jest „streszczony” tylko do wolności-samowoli, w oderwaniu od prawdy i od pozostałych „uniwersaliów” (por. Seifert, 1991, s. 38-48; Melina, 1991, s. 94-112; Kowalczyk, 1984, s. 279-292; Dec, 1984, s. 293-298; Bukowski, 1984, s. 239-256; Majka, 1983, s. 33-49; Krupa, 1983, s. 51-72; Bartnik, 1983, s. 83-101; Dec, 1983, s. 153-172; Czarny, 1983, s.173-199).

W takiej sytuacji media praktycznie sprowadzają ludzi do życia w przeświadczeniu, że nie istnieją jakiekolwiek inne normy postępowania poza ludzką samozależnością, co więcej - media przywłaszczają sobie prawo do współkonstytuowania ludzkiej tożsamości i tym samym nie chronią ludzi - poprzez rozmaite manipulacje medialne - przed groźbą poddania ich w niewolę „obcych prawd”, dokonując nieznanej wcześniej alienacji. Dlatego istnieje dziś konieczność demaskowania pseudoabsolutów moralno-medialnych w imię wyzwolenia osoby zgodnie z pełną prawdą o człowieku. Wizja osoby ludzkiej jako czystej samozależności kłóci się najwyraźniej z danymi doświadczenia życiowego. Tymczasem wiele mediów uczestniczy z dużym zaangażowaniem w ideologii „cywilizacji śmierci”, opierającej się na fałszywej wizji człowieka, którą może sfalsyfikować nawet zwyczajny „zdrowy rozsądek”.

Gdy co raz przeciągają przez środki społecznego przekazu dyskusje o życiu, należy pamiętać, że minione czasy skompromitowały dziennikarstwo pozostające na usługach jakiejkolwiek ideologii. Świadomość olbrzymich możliwości kształtowania ludzkiego sposobu myślenia i wartościowania, nie idzie w parze z odpowiedzialnością za słowo, z sumiennym studium zagadnień i z troską o ustawiczny rozwój dojrzałości wewnętrznej. Stwarzanie wrażenia, że się jest doskonale poinformowanym, zbyt często skrywa rzeczywistą powierzchowność wiedzy i informacji. Mamy nadzieję, że dziennikarze, którzy tak wysoko cenią sobie wolność słowa, również w stosunku do małżeństwa i rodziny zechcą $z$ tej wolności we właściwy sposób skorzystać. Mamy nadzieję, że zapragną wreszcie szukać prawdy i służyć prawdzie o człowieku z całą wewnętrzną wolnością (Konferencja Episkopatu Polski, 2009, nr 163).

\section{Klimat sensu i bezsensu}

Mówi się od dawna, że „media produkują ludzkie sensy”. Trzeba też powiedzieć, że w jakimś nadmiarze „produkują bezsensy” życia. Jest to klimat produkcyjny bardzo mocno rzutujący na współczesne życie rodzinne (por. Popielisk, 1987, s. 23n; Popielisk, 
1996, s. 86n). Media, jeśli mają spełnić swe zadania - i to nie tylko wobec zdrowia duchowego i fizycznego rodziny, muszą być zawsze „po stronie sensu” (por. Po stronie sensu, 1995, s. 51-65). Takie opowiedzenie się wyklucza wszelkie manipulacje medialne. Każdy racjonalnie myślący człowiek wie, że to fundamentalnie rodzina jest „źródłem" kształtowania sensu życia. Sens życia ludzkiego jest najściślej związany z kształtowaniem świadomości i postaw wiary zbawczej (Jan Paweł II, 1981, nr 17; Benedykt XVI, 2006, s. 8) ${ }^{1}$. Patrząc na współczesną kulturę medialną, studiując dokumenty Magisterium Kościoła poświęcone mediom, można zauważyć, że główny akcent kładzie się na pytanie nie tyle, czy życie ma sens, ile jaki ma sens i jaki kształt i treść powinny zawierać przekazy medialne, by spełnić głębokie aspiracje człowieka do osiągnięcia pełni człowieczeństwa. Kultura wizualna bowiem, pozostająca obecnie pod silnym wpływem współczesnych ateizujących i postmodernistycznych humanizmów i wywodzących się z nich etyk, prezentuje w tym przedmiocie bardzo zróżnicowane stanowiska. Jest dużo programów dobrych i wartościowych (tego nikt nie może zakwestionować), ale też ogromnie dużo jest w niej propagowania zwyczajnego konsumizmu, a nawet prymitywnego hedonizmu, rodzącego bezsens.

Trzeba powiedzieć, że tylko nieliczne media troszczą się o kształtowanie sensu życia zgodnego w Ewangelią. Postawa chrześcijanina jest postawą czynną, jest postawą nieustannej przemiany, metanoi, przekraczania i śmierci „starego człowieka”, by żył w nim Chrystus. Tę powinność nieustannego nawracania się wyraził plastycznie Karl Rahner, mówiąc: „Chrześcijaninem jest się po to, by nim się naprawdę stać” (por. Łukaszyk, 1971, s. 143-167).

Człowiek staje się człowiekiem wiary przede wszystkim w rodzinie, „domowym Kościele”. Kiedy mówimy od rodzinie jako o „źródle” kształtowania sensu, to tym samym mówimy o niej jako o „źródle” postaw wiary. Pojęcie postawy rodzi się w odniesieniu człowieka - podmiotu do innej rzeczywistości, którą może być także świat osób. Stąd postawa ma swe wymiary intelektualne, emocjonalne i behawioralne. Rozumiejąc przez postawę ludzką „względnie stałe ustosunkowanie, które wyraża się w gotowości podmiotu do pozytywnych lub negatywnych reakcji intelektualno-orientacyjnych, emocjonalno-motywacyjnych, oraz behawioralnych wobec jej przedmiotu", możemy uznać, że postawa chrześcijańska jest tym wypadkiem postawy ludzkiej, która swą genezę zawdzięcza światu chrześcijańskiemu i rodzi się na gruncie chrześcijańskiej świadomości i chrześcijańskich wartości (Prężyna, 1981, s. 20).

Pozostając w tej perspektywie, widać, że rodzina jest żywym organizmem, w którym następuje wzajemna wymiana darów. Ponieważ to z wiary wynika wychowanie, w którym podstawą są wartości, nazywane chrześcijańskimi, dlatego też rodzina stanowi pierwszy i najważniejszy fundament przekazywania i uczestnictwa w „sensie”. Wynika to także

1 Do tej prawdy nawiązuje Benedykt XVI uczestniczący w V Światowym Spotkaniu Rodzin w Walencji w dniach 8 i 9 lipca 2006 r. Do zgromadzonych na spotkaniu rodzin wygłosił on dwie homilie jedną 8 lipca podczas czuwania modlitewnego, które odbyło się w Miasteczku Sztuki i Nauki, drugą 9 lipca podczas mszy odprawionej na zakończenie spotkania, także w Miasteczku Sztuki i Nauki. 


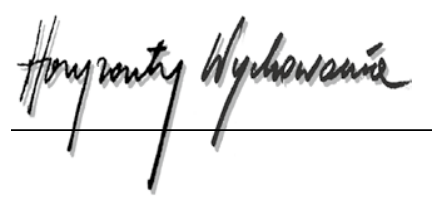

z całego wychowania chrześcijańskiego. Cały proces ewangelizacyjny nie jest niczym innym jak „usensowieniem” ludzkiego życia i szansą dla wychodzenia z wszelakiego rodzaju bezsensów życiowych. Bez Ewangelii - życie ludzkie nie ma sensu. Ewangelizacja jest czymś nieodłącznym od moralności indywidualnej i społecznej. I w ten sposób wpisuje się w mediosferę. Badania empiryczne ukazują, że ludzie dziś odczuwają „swoisty głód ducha”, konfrontowany z preferowanym medialnie sytuacjonizmem etycznym. Zanik świadomości osobistej zła i odpowiedzialności moralnej za popełnione czyny u współczesnego człowieka staje się coraz bardziej widoczny, przybierając niepokojące rozmiary szerzącej się powszechnie degradacji i obojętności dla wszystkiego, co określa istotne aspekty życia społecznego (por. Jan Paweł II, 1993, nr 34; Kupczak, 1999, s. 99; Jan Paweł II, 1998, nr 14; Borne, 1968; Cofty, 1968; de Lubac, 1969; Echarren, 1970, s. 159-168). Coraz częściej obserwuje się przypadki jawnego lekceważenia podstawowych zasad moralności, stojących na przeszkodzie - zdaniem wielu - do osiągnięcia szczęścia i prawdziwej wolności. Zdrada prawdy umieszczona jest jakby programowo w tzw. sytuacjonizmie etycznym. W tym klimacie „sytuacyjnym”, rozpowszechnianym codziennie przez liczne media, rozstrzygającą i ostateczną normą działania nie jest właściwy porządek obiektywny, wyznaczony prawem moralnym i poznany w sposób pewny na podstawie tego prawa, ale „sytuacyjne” i często przypadkowe osądy każdego indywidualnego człowieka. Takie podejście prowadzi w rezultacie do zakwestionowania wiążących norm moralnych (Góralczyk, 2000, s. 100). To powoduje osłabienie ludzkich sumień i tym samym degradację życia rodzinnego.

\section{Zakończenie}

W zakończeniu trzeba powiedzieć, że media są takie, jacy są ludzie. A ludzie są tacy, jaki jest rzeczywisty stan ich sumień - dobry albo zły. Z powyższych analiz wynikają przede wszystkim trzy wnioski.

Pierwszy - dotyczy właściwego rozumienia wolności ludzkiej. Wolność bywa pojmowana najczęściej jako wyzwolenie. Pierwotne rozumienie wolności posiadali już starożytni Grecy, skoro określali ją mianem eleutheria, czyli uwolnienie od więzów. Tak jakby początkowym doświadczeniem człowieka była niewola, jakieś kajdany, z których człowiek wskutek takich czy innych przyczyn się wyzwolił. Temu wyzwoleniu towarzyszy przekonanie, że odtąd człowiek ma możliwość wyzwolenia się spod wszelkich uzależnień. Dotyczy to także w naszym wypadku wyzwolenia od niesprawiedliwych i zniewalających uzależnień złych mediów. Wolność nie jest czymś pierwszym i absolutnym, gdyż zawsze posiada podstawowe odniesienie do prawdy, która decyduje o tym, czy dana wolność jest wolnością prawdziwą, czy też jedynie pozorną (por. Jędraszewski, 1992, s. 8-14).

Drugi wniosek etyczny dotyczy tego, że nie wolno handlować ludzkimi przekonaniami. Zasada ta obejmuje również wszystkie media. Media stosują dosyć powszechnie mechanizm zniewalania człowieka przez iluzję i kłamstwo. Towarzyszy to człowiekowi od samych początków jego dziejów. Dziś polega on na tym, że człowiekowi obiecuje się 
jeszcze większą wolność niż ta, jaką dotychczas się cieszył, ale ta obietnica jest iluzją i kłamstwem. Nie prowadzi bowiem do wolności, lecz do zniewolenia. „Człowiek jednak nie jest ćmą. Może odrzucić zdradliwą obietnicę. Wystarczy, że konsekwentnie będzie się trzymał autentycznego porządku wartości. Że nad kłamstwem, które kryje się za tą obietnicą; zatryumfuje prawda, która tkwi w autentycznej wartości" (por. Jędraszewski, 1992, s. 11-12). Jeżeli mówi się, że „media kłamią”, to tym samym mówimy, że tylko obiecują coś, czego w rzeczywistości nie ma. Nie tylko obiecują (większą) wolność, ale niosą zniewolenie. Niekiedy staje się ono jeszcze bardziej bezczelne. Nakłania do świadomego oddania wolności w zamian za mniej lub bardziej wymierne dobra. Jego skuteczność polega na tym, że ukazuje wolność nie jako wartość najwyższą, ale, przeciwnie, jako dużo mniej wartą od innych, jako coś, czego należy się wyrzec dla czegoś innego, bardziej cennego (por. Jędraszewski, 1992, s. 12).

I wniosek trzeci - wskazuje on na to, że media, jak każde ludzkie dzieło - dobre albo złe - mogą służyć albo doskonaleniu się osoby i rodziny, albo upodleniu wynikającemu z własnowolnego zniewolenia. Upada wtedy dusza człowieka. Stawka jest więc olbrzymia: własne człowieczeństwo. Dlatego wieloraka troska o jakość etyczną mediów jest równocześnie troską o dobro rodziny w świecie mediów.

\section{BIBLIOGRAFIA}

Bartnik, C. (1983). Osoba i Kościół według Kard. K. Wojtyły. Colloquium Salutis, 15, 83-101.

Benedykt XVI. (2006). Rodzino żyj i przekazuj wiarę! Rozważania papieskie przed modlitwą „Anioł Pański'. L'Osservatore Romano, wyd. polskie, 9-10, 8.

Benedykt XVI. (2007). Dzieci i środki przekazu jako problem wychowawczy. L'Osservatore Romano, wyd. polskie, 3, 5-7.

Bogucka, T. (2000). Polska bieda. Polis, 1-2, 20-25.

Borne, E. (1968). Bóg nie umarł. Studium o współczesnym ateizmie. Paris: Editions du Dialogue. Brozi, K. (1992). Ludzie i kryzys cywilizacji. Szkice antropologiczne. Lublin: Norbertinum.

Bukowski, K. (1984). Filozof osoby i miłości - Maurice Nédoncelle. Colloquium Salutis, 16, 239-256.

Burakowska, K. (1996). Cywilizacja w procesie przemian. Gdańsk: Wydawnictwo Uniwersytetu Gdańskiego.

Burszta, W.J. (1999). Wirtualizacja kultury i co z tego wynika. W: M. Kempny i G. Woroniecka (red.), Religia i kultura w globalizującym się świecie. Kraków: Nomos, 25-38.

Buttiglione, R. (1991a). L'uomo e la famiglia. Roma: Dino Editore.

Buttiglione, R. (1991b). La crisi della morale. Roma: Dino Editore.

Buttiglione, R. (1995). Ekonomia a etyka: chrześcijańska doktryna społeczna w zmieniającym się świecie. Znak, 1, nr 476, 95-103.

Cofty, R. (1968). Bóg niewierzących. Paris: Éditions du Dialogue : Société d'Éditions Internationales.

Crosby, J. (2004). Czy rzeczywiście wszelkie zło jest tylko brakiem? Ethos, 65-66, 12-20.

Czarnik, T. (1996). Status wartości w czasach przemian współczesnych. W: Z. Sareło (red.), Moralność i etyka w ponowoczesności. Warszawa: Wydawnictwa Akademii Teologii Katolickiej, 55-61.

Czarny, J. (1983). Człowiek odkupiony przez Chrystusa - kim jest? (Nauczanie Kard. K. Wojtyły). Colloquium Salutis, 15, 173-199.

Czerwiński, M. (1999). Kultura elitarna a kultura masowa. W: Encyklopedia socjologii, t. 2. Warszawa: Oficyna Naukowa, 110-116. 


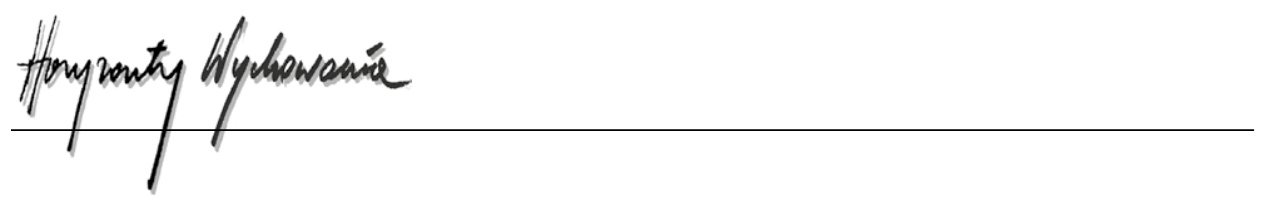

Dec, I. (1983). Podmiotowość osoby w ujęciu Kardynała K. Wojtyły. Z filozoficznego zaplecza encyklik Jana Pawła II. Colloquium Salutis, 15, 153-172.

Dec, I. (1984). Ontyczne racje danych samodoświadczenia człowieka w ujęciu św. Tomasza z Akwinu. Colloquium Salutis, 16, 293-298.

De Lubac, H. (1969). Ateizm i sens człowieka. Paris: Editions du Dialogue.

Drożdż, A. (1998). Konsumizm. Tarnów: Wydawnictwo Diecezji Tarnowskiej Biblos.

Drożdż, M. (2005). Osoba i media. Personalistyczny paradygmat etyki mediów. Tarnów: Wydawnictwo Diecezji Tarnowskiej Biblos.

Drożdż, M. (2006). Media w przestrzeni odpowiedzialności za rodzinę. W: E. Osewska i J. Stala (red.), Rodzina. Bezcenny dar i zadanie. Radom: Polwen Polskie Wydawnictwo Encyklopedyczne, 771-808.

Dyczewski, L. (2001). Najważniejsze są wartości. W: L. Dyczewski (red.), Kultura w kręgu wartości. Lublin: Towarzystwo Naukowe Katolickiego Uniwersytetu Lubelskiego, 311.

Echarren, R. (1970). Przekazywanie wiary z punktu widzenia uwarunkowań struktur społecznych w obecnej dobie. Concilium, 1-5, 159-168.

Franciszek. (2013). Adhortacja apostolska Evangelii gaudium, nr 53, 54, 55, 66, 203, 206.

Garello, J. (2002). Wolność i uczestnictwo w ujęciu Karola Wojtyły. Ethos, 59-60, 355-369.

Góralczyk, P. (2000). Sumienie a prawda i wolność. Communio, 1, 100.

Goban-Klas, T. (2005). Społeczeństwo masowe, informacyjne, sieciowe czy medialne? Ethos, 69-70, 10-114.

Jan Paweł II (1981). Adhortacja apostolska Familiaris consortio. Watykan, nr 17.

Jan Paweł II (1993). Encyklika Veritatis splendor. Watykan, nr 34.

Jan Paweł II (1998). Encyklika Fides et ratio. Watykan, nr 14.

Jan Paweł II (2002a). Komunikacja społeczna pomostem między wiarą i kulturą. W: Orędzia Papieskie na Światowy Dzień Komunikacji Społecznej 1967-2002, oprac. M. Lis. Częstochowa, 90-96.

Jan Paweł II (2002b). Komunikacja społeczna pomostem między wiarą i kulturą. W: Orędzia Papieskie na Światowy Dzień Komunikacji Społecznej 1967-2002, oprac. M. Lis, Częstochowa, 120-127.

Jan Paweł II (2002c). Komunikacja społeczna w służbie chrześcijańskiej promocji młodzieży. W: Orędzia Papieskie na Światowy Dzień Komunikacji Społecznej 1967-2002, oprac. M. Lis, Częstochowa, 128-138.

Jan Paweł II (2002d). Komunikacja społeczna w służbie odpowiedzialnej wolności człowieka. W: Orędzia Papieskie na Światowy Dzień Komunikacji Społecznej 1967-2002, oprac. M. Lis, Częstochowa, 97-105.

Jan Paweł II (2002e). Komunikacja społeczna w służbie pokoju. W: Orędzia Papieskie na Światowy Dzień Komunikacji Społecznej 1967-2002, oprac. M. Lis, Częstochowa, 114-119.

Jan Paweł II (2005). List apostolski o mediach Szybki rozwój. Watykan.

Jędraszewski, M. (1992). Domem wolności jest prawda. W Drodze, 10, 8-14.

Krąpiec, M.A. (1965). Przeżycie moralne a etyka. Znak, 17, 1129-1146.

Konferencja Episkopatu Polski. (2009). Służyć prawdzie o małżeństwie i rodzinie. Warszawa, $\mathrm{nr} 162$ i 163.

Kowalczyk, S. (1984). Koncepcja wolności odpowiedzialnej Jakuba Maritaina. Colloquium Salutis, 16, 279-292.

Krupa, O.A. (1983). Człowiek w tajemnicy Chrystusa, Maryi i Kościoła - nauka Kard. K. Wojtyły. Colloquium Salutis, 15, 51-72.

Kupczak, J. (1999). W stronę wolności. Szkice o antropologii Karola Wojtyły. Kraków: KAIROS.

Laun, A. (1991). Aktuelle Probleme der Moraltheologie. Wien: Herder.

Lepa, A. (2001). Media i postawy. Łódź: Archidiecezjalne Wydawnictwo Łódzkie. 
Łukaszyk, R. (1971). Osobowy charakter wiary religijnej. W: B. Bejze (red.), W kierunku człowieka. Warszawa: Wydawnictwo Uniwersytetu Kardynała Stefana Wyszyńskiego, 143-167.

Majka, J. (1983). Człowiek w encyklikach Jana Pawła II. Colloquium Salutis, 15, 33-49.

Melina, L. (1991). Sumienie - wolność - Magisterium. Ethos, 15-16, 94-112.

Piłat, R. (2001). Miejsce wartości moralnych w ocenach historycznych. Ethos, 56, 251-259.

Popielski, K. (1987). Człowiek pytanie otwarte. Lublin: Redakcja Wydawnictw KUL.

Popielski, K. (1996). Człowiek - wartości - sens. Studia z psychologii egzystencji. Logoteoria i nooteoria. Logoterapia i nooterapia. Lublin: Redakcja Wydawnictw KUL.

Po stronie sensu. Ze Stanisławem Barańczakiem rozmawia Magdalena Ciszewska oraz Roman Baj i Paweł Kozacki (1995). W Drodze, 10, 51-65.

Półtawski, A. (2004). Wartości a osoby. Wartości - podstawowa kategoria bytu czy wyraz ontologicznej bezradności? Ethos, 65-66, 41-51.

Prężyna, W. (1981). Funkcja postawy religijnej w osobowości człowieka. Lublin: Katolicki Uniwersytet Lubelski.

Rodziny, żyjcie radością wiary. (2013). Pozyskano z: http://papiez.wiara.pl/doc/1754972.Rodziny-zyjcie-radoscia-wiary/2 (dostęp: 20.01.2020).

Seifert, J. (1991). Sumienie, poznanie, prawda. Ethos, 15-16, 38-48.

Stróżewski, W. (1965). Filozofia wartości. Znak, 17, 399-407.

Styczeń, T. (1991). Osoba ludzka: wolność przeciw naturze? Ethos, 15-16, 15-24.

Szostek, A. (1990). Natura - rozum - wolność. Filozoficzna analiza koncepcji twórczego rozumu we współczesnej teologii moralnej. Rzym: Fundacja Jana Pawła II.

Zawsze ufajcie Bogu. (2013). Pozyskano z: http://papiez.wiara.pl/doc/1729063.Spotkanie-Papieza-z-mlodzieza (dostęp: 20.01.2020).

\section{Copyright and License}

This article is published under the terms of the Creative Commons Attribution - NoDerivs (CC BY- ND 4.0) License http://creativecommons.org/licenses/by-nd/4.0/ 